\section{Optimum Height at Which to Kill Barley Used as a Living Mulch in Onions}

\author{
Richard G Greenland ${ }^{1}$ \\ Oakes Irrigation Research Site, North Dakota State University Agricultural \\ Experiment Station, Oakes, ND 58474-0531
}

Additional index words. cover crop, fluazifop-P, planting configuration, crop competition, soil erosion, wind damage, Hordeum vulgare, Allium cepa

\begin{abstract}
Planting barley (Hordeum vulgare L.) as a living mulch with onions (Allium cepa L.) reduces soil erosion and protects the onions from wind damage. It can also reduce yield and size of onion bulbs if not managed correctly. In a 4-year study at the Oakes Irrigation Research Site in North Dakota, barley was planted in the spring at the same time that onions were direct-seeded. Barley rows were planted either parallel with or perpendicular to the onion rows. Barley was killed with fluazifop-P herbicide when $\approx 13,18,23$, or $30 \mathrm{~cm}$ tall. Onion size and yields were reduced when barley was allowed to grow taller than 18 cm before killing it. Total onion yield was usually greater when barley was planted parallel with, rather than perpendicular to, onion rows. Chemical name used: (R)-2-[4-[[5(trifluoromethyl)-2-pyridinyl]oxy]phenoxy]propanoic acid (fluazifop-P).
\end{abstract}

In North Dakota and many other areas of the northern United States, onions are directseeded in the spring into a conventionally tilled, finely prepared seed bed. Very little residue remains on the soil surface. One reason this is necessary is because many onion planters do not work well in no-till or stubbletilled fields. High winds, which frequently occur in the spring, blow the soil particles from the finely prepared seed bed across the ground, causing extensive damage to newly emerged onion seedlings. Some areas of the field are completely denuded of onion plants, while in other areas the onion stand is reduced and plants are weakened.

Cover crops reduce soil erosion, protect plants from blowing soil particles, help control weeds, enhance water penetration and retention, improve soil structure, help maintain or increase soil organic matter, and may increase yields (Barnes and Putnam, 1983; Masiunas et al., 1995, 1997; Mwaja et al., 1996; Schonbeck et al., 1993). They may also reduce yield and quality of the principal crop by competing with the crop for water, light, and nutrients (Bottenberg et al., 1999; Masuinas et al., 1997).

Cover crops that are planted before, at the same time, or after the principal crop and grow with the crop are often referred to as living mulches. A major purpose of living mulches is to provide protection against wind-blown soil

\footnotetext{
Received for publication 11 Aug. 1999. Accepted for publication 11 Jan. 2000. I thank the Garrison Diversion Conservancy District, State of North Dakota, for financial support. I thank Leonard Besemann and Heidi Eslinger for their help in conducting this study. The cost of publishing this paper was defrayed in part by the payment of page charges. Under postal regulations, this paper therefore must be hereby marked advertisement solely to indicate this fact.

${ }^{1}$ Associate Agronomist with the Agricultural Experiment Station and Research Supervisor at the Oakes Irrigation Research Site. E-mail: rgreenla@ ndsuext.nodak.edu
}

particles. A living mulch should be chosen that does not compete with the principal crop, or the living mulch must be restricted or killed to prevent competition. The taller a living mulch grows, the greater the protection against wind erosion and wind damage. If it grows too tall, it competes with the crop, and yield and quality are reduced.

How long a living mulch can grow before causing crop yield reductions depends on the crop, the mulch, and other factors. Zandstra and Warncke (1993) reported that carrot (Daucus carota L.) yields were not reduced if the barley living mulch was killed at 20 and 40 $\mathrm{cm}$ tall when broadcast-seeded at 108 and 54 $\mathrm{kg} \cdot \mathrm{ha}^{-1}$, respectively. They reported that barley interseeded (broadcast) with onions had to be killed when 10 to $20 \mathrm{~cm}$ tall to avoid onion yield reduction. This would be $\approx 1$ week after onion emergence. Lanterman et al. (1984) observed no onion yield reductions when barley was broadcast-seeded at $54 \mathrm{~kg} \cdot \mathrm{ha}^{-1}$ if the living mulch was killed before it exceeded 12 $\mathrm{cm}$ in height. Onion yield also was not reduced if barley planted at $7 \mathrm{~kg} \cdot \mathrm{ha}^{-1}$ in a single row between every two rows of onions was killed before it reached $30 \mathrm{~cm}$ tall. In competition studies with weeds, Wicks et al. (1973) reported small (sometimes nonsignificant) reductions in yield and size of onions when weeds were allowed to grow unchecked for 2 weeks after onion emergence. Hewson and Roberts (1971) reported that final onion yield was unaffected when weeds remained for up to 4 to 6 weeks after $50 \%$ crop emergence, provided that the crop was subsequently kept weed-free.

Of the 14 crops they screened in Oklahoma, Nelson et al. (1991) identified rye (Secale cereale L.), barley, and wheat (Triticum aestivum $\mathrm{L}$.) as the most promising springseeded cover crops, with respect to cover density and competitiveness against weeds. Zandstra and Warncke (1993) preferred barley to other cereal grasses because of its upright growth habit and ease of killing with herbicides. In previous research I found that a barley cover crop seeded simultaneously with onions emerged rapidly, grew vigorously, and was usually 5 to $10 \mathrm{~cm}$ tall when the onions emerged (Greenland, unpublished). Oats (Avena sativa L.), spring wheat, and rye were not as well suited for a living mulch as was barley because of slower growth, a less robust stand, or a prostrate growth habit.

The objective of this study was to determine how tall a barley living mulch, planted in rows either perpendicular or parallel to onion rows, should be allowed to grow before killing it to prevent it from reducing onion yield.

\section{Materials and Methods}

This field study was conducted from 1995 to 1998 at the North Dakota State Univ., Oakes Irrigation Research Site, in southeast North Dakota. The soil was a Maddock (1996-98) or Egeland (1995) sandy loam (both are Udorthentic Haploborolls) with a pH of 7.2 to 7.4 and $2.4 \%$ to $2.7 \%$ organic matter. Onions followed cabbage (Brassica oleracea $\mathrm{L}$. var. Capitata), soybean (Glycine max L.), potato (Solanum tuberosum L.), and carrot in 1995, 1996, 1997, and 1998, respectively. The field was disked twice, then cultivated twice before planting onions in 1996. In 1995, 1997, and 1998 , seed bed preparation consisted of only one disking and one cultivation.

The barley cover crop was planted on 26 Apr. 1995, 18 Apr. 1996, 25 Apr. 1997, and 15 Apr. 1998 at a rate of $54 \mathrm{~kg} \cdot \mathrm{ha}^{-1}$. The barley was planted perpendicular to the onion rows all 4 years using a grain drill with $15-\mathrm{cm}$ row spacings. This same grain drill was used to plant barley parallel with the onions in 1995 and 1996; some of the drill rows were not planted to allow room for the onion rows, and seeding rate was adjusted in the drill rows to maintain a rate of $54 \mathrm{~kg} \cdot \mathrm{ha}^{-1}$. The barley was planted first, followed by a second pass to plant the onions. In 1997 and 1998, modification of the onion planter by mounting a grain drill on it allowed planting of two parallel rows of barley between every two onion rows in one pass. Onions were planted $1 \mathrm{~d}$ after the barley in 1995 and on the same day the barley was planted in 1996-98. A precision belt planter (Stanhay S870; Stanhay Webb, Ltd., Newmarket, Suffolk, England) was used to plant onions in double rows ( $7 \mathrm{~cm}$ apart) on 40$\mathrm{cm}$ centers. Seeding rate was $\approx 500,000$ seeds per hectare. The onion hybrids used were 'Golden Treasure' in 1995 and 'Santos' in 1996-98.

The fields were overhead sprinkler irrigated as needed, and N, P, K, and S fertilizers were applied per Univ. of Minnesota recommendations. Weeds were controlled with DCPA (dimethyl 2,3,5,6-tetrachloro-1,4benzenedicarboxylate) in 1996, pendimethalin [N-(1-ethylpropyl)-3,4-dimethyl-2,6-dinitrobenzenamine] in 1997 and 1998, bromoxynil (3,5-dibromo-4-hydroxybenzonitrile) plus oxyfluorfen [2-chloro-1-(3-ethoxy-4nitrophenoxy)-4-(trifluoromethyl)benzene] in all years, and by hand-weeding. Fluazifop-P, used to kill the barley cover crop, also con- 
trolled grass weeds. Purple blotch [Alternaria porri (Ellis)] and downy mildew [Peronospora destructor (Berk.)] were controlled with chlorothalonil (tetrachloroisophthalonitrile), mancozeb (ethylene bisdithiocarbamate), mefenoxam \{(R)-2-[(2,6-dimethylphenyl)methoxyacetylamino]-propionic acid methyl ester ], and iprodione [3-(3,5-dichlorophenyl)$\mathrm{N}$-(1-methylethyl)-2,4-dioxo-1-imidazolidinecarboxamide]. Spraying with fungicides was initiated when disease was first seen in the experimental fields or in adjacent ones, and was continued on a regular basis until just before harvest or until conditions no longer warranted treatment. No insecticides were needed.

Barley was killed by spraying it with fluazifop-P. The fluazifop-P (plus a nonionic surfactant) was applied in $425 \mathrm{~L} \cdot \mathrm{ha}^{-1}$ of water at $200 \mathrm{kPa}$ pressure using a $\mathrm{CO}_{2}$ backpack sprayer, except for the last application each year; the last treatment was applied to the entire area using a tractor-mounted sprayer (340 L·ha $\left.{ }^{-1} ; 205 \mathrm{kPa}\right)$, and killed any barley not previously sprayed, plus any grass weeds present (usually $<1 \mathrm{~m}^{2}$ ). Time of killing the barley cover crop is shown in Table 1 . The rate of fluazifop-P ranged from $120 \mathrm{~g} \cdot \mathrm{ha}^{-1}$ when the barley was small to $388 \mathrm{~g} \cdot \mathrm{ha}^{-1}$ when taller. The bromoxynil plus oxyfluorfen herbicide treatment was applied 3 to $20 \mathrm{~d}$ after the last fluazifop-P treatment.

Onions were hand-pulled and placed in a windrow in mid-September, allowed to field cure for 2 to 4 weeks, then were bagged and stored in a shed until grading. In early November bulbs were sorted by size, counted, and weighed. Percentage of single-centered onions was determined using a randomly selected sample of five large bulbs from each plot. Visual grades of uniformity and of overall appearance of the bulbs from each plot were recorded.

Because of nearby corn fields, shelter belts, or buildings, the onions were not exposed to the high winds common in the area. Therefore, this study probably did not detect the effects on onions of protection from wind damage. On 2 July 1998, I measured the height of the dead barley mulch and the percentage of ground it covered to provide some idea of the wind protection the barley would give the onions. Percent groundcover was determined using a line-intercept method with a 0.9 -m measuring stick marked at $2.5-\mathrm{cm}$ intervals. I also determined the size and growth stage of the onions on that date.

Average temperatures for Oakes, N.D., are $13,18,22,21$, and $13{ }^{\circ} \mathrm{C}$ for May, June, July, August, and September, respectively, and average precipitation for the same months is 35 , $50,41,47$, and $33 \mathrm{~mm}$, respectively. Spring 1995 was cool and wet, delaying field work and planting. June through August temperatures were average to above average. Spring 1996 was cool and wet, but onion planting was not delayed. Crops developed slowly during the spring. Temperatures from June through the end of the season were near average. Record snowfall in Winter 1996-97 did not melt until late April, delaying planting in 1997. Temperatures were below average in April and
May, but average or above average the rest of the year. In 1998, temperatures were near average and precipitation was above average.

A split-plot experimental design was used, with direction of planting barley as the main plots and time of killing barley as the subplots. Main plots were $9.8 \times 4.2 \mathrm{~m}$, and were divided into four subplots, $4.2 \times 1.8 \mathrm{~m}$, with a $0.6-\mathrm{m}$ border between subplots. The data were analyzed using the SAS GLM and regression procedures (SAS Institute, 1989). Because of very significant year $\times$ barley height interactions, data for each year were analyzed separately.

\section{Results and Discussion}

Effect of barley height when killed. Allowing the barley to grow taller before killing it did not reduce the total number of onion bulbs harvested except in 1996 and 1997, and then only at the tallest barley height (Table 2). However, the number of large onions was reduced each year at the tallest barley height. In 1998, there was a clear shift from large onions to medium and small onions as barley height at spraying increased. Stress on the plant from competition with barley reduced bulb size.

The first derivative of the regression equations showed that the highest large and total onion yields occurred at the lowest barley height. However, yields of large onions when barley was killed at 15,23, and $17 \mathrm{~cm}$ tall (for 1995, 1996, and 1997, respectively) were not significantly different from those at the lowest barley height. Total onion yields when barley was killed at $15,18,23$, and $18 \mathrm{~cm}$ tall (for 1995, 1996, 1997, and 1998, respectively) were not significantly different from those

Table 1. Rates and timing of fluazifop-P applications used to kill the barley living mulch. A nonionic surfactant was included with each application.

\begin{tabular}{|c|c|c|c|c|c|}
\hline \multirow[b]{2}{*}{ Year } & \multirow{2}{*}{$\begin{array}{l}\text { Application } \\
\text { date }\end{array}$} & \multirow{2}{*}{$\begin{array}{l}\text { Fluazifop-P } \\
\text { (g.ha-1 a.i.) }\end{array}$} & \multicolumn{2}{|c|}{ Plant height $(\mathrm{cm})$} & \multirow{2}{*}{$\begin{array}{c}\text { Onion } \\
\text { growth stage }\end{array}$} \\
\hline & & & Barley & Onion & \\
\hline \multirow[t]{3}{*}{1995} & 23 May & 140 & 13 & 3 & Cotyledon \\
\hline & 25 May & 280 & 15 & 5 & Cotyledon \\
\hline & 30 May & 280 & 25 & 7 & 1 True leaf \\
\hline \multirow[t]{4}{*}{1996} & 20 May & 216 & 13 & 3 & Cotyledon \\
\hline & 23 May & 280 & 18 & 4 & Cotyledon \\
\hline & 30 May & 388 & 23 & 4 & 1 True leaf \\
\hline & 4 June & 385 & 30 & 8 & 2 True leaves \\
\hline \multirow[t]{4}{*}{1997} & 20 May & 140 & 10 & 2 & Cotyledon \\
\hline & 27 May & 162 & 17 & 4 & 1 True leaf \\
\hline & 29 May & 210 & 23 & 7 & 11/2 True leaves \\
\hline & 4 June & 210 & 30 & 9 & 2 True leaves \\
\hline \multirow[t]{4}{*}{1998} & 5 May & 140 & 10 & 2 & Just emerged \\
\hline & 15 May & 270 & 18 & 4 & 1/2 True leaf \\
\hline & 21 May & 323 & 23 & 8 & 1 True leaf \\
\hline & 26 May & 323 & 30 & 9 & 1 True leaf \\
\hline
\end{tabular}

Table 2. The effect of height of barley living mulch when killed on number of onion bulbs harvested and onion yields.

\begin{tabular}{|c|c|c|c|c|c|c|c|c|}
\hline \multirow{2}{*}{$\begin{array}{l}\text { Barley } \\
\text { height when } \\
\text { sprayed }(\mathrm{cm})\end{array}$} & \multicolumn{4}{|c|}{ No. of bulbs harvested (1000s/ha) } & \multicolumn{4}{|c|}{ Onion yield $\left(\mathrm{Mg} \cdot \mathrm{ha}^{-1}\right)$} \\
\hline & $\operatorname{Large}^{z}$ & Medium $^{2}$ & Small $^{\mathrm{z}}$ & Total & Large $^{z}$ & Medium $^{2}$ & Small $^{\mathrm{Z}}$ & Total \\
\hline & \multicolumn{8}{|c|}{1995} \\
\hline 13 & $84 a^{y}$ & 109 & 44 & 264 & $24.5 \mathrm{a}$ & 17.8 & 3.1 & $50.8 \mathrm{a}$ \\
\hline 15 & $79 \mathrm{a}$ & 106 & 42 & 252 & $23.2 \mathrm{a}$ & 16.9 & 2.8 & $47.8 \mathrm{a}$ \\
\hline 25 & $62 \mathrm{~b}$ & 116 & 54 & 259 & $17.1 \mathrm{~b}$ & 18.1 & 3.5 & $42.8 \mathrm{~b}$ \\
\hline \multirow[t]{2}{*}{$R^{2}$} & $0.36^{* * *}$ & NS & NS & NS & $0.39^{* * * *}$ & NS & NS & $0.27^{* *}$ \\
\hline & \multicolumn{8}{|c|}{1996} \\
\hline 13 & $167 \mathrm{a}$ & 197 & 65 & $461 \mathrm{a}$ & $48.2 \mathrm{a}$ & 31.8 & 4.4 & $90.0 \mathrm{a}$ \\
\hline 18 & $174 \mathrm{a}$ & 179 & 73 & $461 \mathrm{a}$ & $49.0 \mathrm{a}$ & 29.0 & 4.7 & $89.1 \mathrm{a}$ \\
\hline 23 & $151 \mathrm{a}$ & 188 & 69 & $441 \mathrm{ab}$ & $42.7 \mathrm{a}$ & 30.0 & 4.5 & $83.0 \mathrm{~b}$ \\
\hline 30 & $100 \mathrm{~b}$ & 173 & 80 & $412 \mathrm{~b}$ & $28.2 \mathrm{~b}$ & 27.2 & 5.2 & $67.6 \mathrm{c}$ \\
\hline \multirow[t]{2}{*}{$R^{2}$} & $0.43^{* * * *}$ & NS & NS & $0.20^{*}$ & $0.44^{* * * *}$ & NS & NS & $0.66^{* * * *}$ \\
\hline & \multicolumn{8}{|c|}{1997} \\
\hline 10 & $181 \mathrm{a}$ & $154 \mathrm{a}$ & 63 & $425 \mathrm{a}$ & $54.7 \mathrm{a}$ & $23.4 \mathrm{a}$ & 4.1 & $88.4 \mathrm{a}$ \\
\hline 17 & $154 \mathrm{a}$ & $157 \mathrm{a}$ & 71 & $415 \mathrm{a}$ & $45.4 \mathrm{ab}$ & $23.7 \mathrm{a}$ & 4.6 & $80.9 \mathrm{a}$ \\
\hline 23 & $148 \mathrm{a}$ & $171 \mathrm{a}$ & 83 & $437 \mathrm{a}$ & $42.7 \mathrm{~b}$ & $26.5 \mathrm{a}$ & 5.3 & $80.1 \mathrm{a}$ \\
\hline 30 & $29 \mathrm{~b}$ & $65 \mathrm{~b}$ & 94 & $247 \mathrm{~b}$ & $7.5 \mathrm{c}$ & $9.4 \mathrm{~b}$ & 5.3 & $25.4 \mathrm{~b}$ \\
\hline \multirow[t]{2}{*}{$R^{2}$} & $0.60^{* * * *}$ & $0.57^{* * * *}$ & NS & $0.59^{* * * *}$ & $0.60^{* * * *}$ & $0.57^{* * * *}$ & NS & $0.65^{* * * *}$ \\
\hline & \multicolumn{8}{|c|}{1998} \\
\hline 10 & $204 \mathrm{a}$ & $94 \mathrm{c}$ & $28 \mathrm{c}$ & 339 & $63.9 \mathrm{a}$ & $15.4 \mathrm{c}$ & $1.8 \mathrm{c}$ & $84.2 \mathrm{a}$ \\
\hline 18 & $181 \mathrm{a}$ & $114 \mathrm{c}$ & $39 \mathrm{c}$ & 351 & $53.6 \mathrm{~b}$ & $18.6 \mathrm{bc}$ & $2.5 \mathrm{bc}$ & $78.3 \mathrm{a}$ \\
\hline 23 & $144 \mathrm{~b}$ & $144 \mathrm{~b}$ & $54 \mathrm{~b}$ & 355 & $42.2 \mathrm{c}$ & $22.5 \mathrm{ab}$ & $3.4 \mathrm{~b}$ & $70.0 \mathrm{~b}$ \\
\hline 30 & $111 \mathrm{c}$ & $175 \mathrm{a}$ & $71 \mathrm{a}$ & 366 & $31.3 \mathrm{~d}$ & $26.8 \mathrm{a}$ & $4.4 \mathrm{a}$ & $63.8 \mathrm{~b}$ \\
\hline$R^{2}$ & $0.45^{* * * *}$ & $0.39^{* * * *}$ & $0.39^{* * *}$ & NS & $0.47^{* * * *}$ & $0.35^{* * *}$ & $0.36^{* * * *}$ & $0.35^{\text {**** }}$ \\
\hline
\end{tabular}

${ }^{\mathrm{z}}$ Large, medium, and small onions are $>7.6 \mathrm{~cm}, 5.7$ to $7.6 \mathrm{~cm}$, and $<5.6 \mathrm{~cm}$ in diameter, respectively. ${ }^{y}$ Mean separation within columns and years determined by $95 \%$ confidence intervals. Ns, *,**,*** Nonsignificant or significant at $P \leq 0.05,0.01$, or 0.001 , respectively. 
when it was killed earlier. In 1998, yields of medium and small onions increased as barley height at spraying increased. Although the time of application at which no significant reduction in onion yield occurred varied slightly from year to year, the $18-\mathrm{cm}$ height seemed to be optimum. In the studies by Zandstra and Warncke (1993), and Lanterman et al. (1984), barley had to be killed at a lower height to avoid onion yield reductions, perhaps because they broadcast-seeded the barley, whereas in this study the barley was planted in rows.

The height at which the barley was killed did not affect percentage of single-centered onions, onion uniformity, or their overall appearance.

Effect of direction of planting barley. Compared with planting barley perpendicular to onion rows, planting barley parallel with the onions decreased total number of onion bulbs in 1995, increased total bulbs in 1996, and did not affect total bulb number in 1997 and 1998 (Table 3). Parallel planting also increased numbers and yield of large onions while reducing those of small onions in 1998. Total onion yield was higher in 1996 and 1998, lower in 1995, and unaffected in 1997 when barley was planted parallel with the onion rows. The reductions in number and yield in 1995 may have been the result of imprecise planting of the onions. Sometimes the planter would swing to the side a few centimeters and plant the onion seed in the barley row. Onions were planted more accurately in 1996, and modifying the planter in 1997 and 1998 so that both onions and barley were planted in a single pass solved the seed placement problem. I conclude that planting the barley parallel with, rather than perpendicular to, the onion rows gives equal or greater yields provided that seed placement is accurate. It also saves one pass over the field.

The orientation of the barley did not affect percentage of single-centered onions, or onion uniformity or overall appearance.

Effect on cover crop remaining and size of onion plants. When its height was measured on 2 July 1998 , the barley that had been sprayed when it was 10 or $18 \mathrm{~cm}$ tall had completely or almost completely disappeared (Table 4). Most of the barley sprayed at the last two spray dates was still erect and covered about one-third of the ground. The taller the barley was allowed to grow before killing it, the shorter and farther behind in development the onion plants were. This delay in development reduced bulb size.

The barley was taller and covered more ground when planted perpendicular to vs. parallel with the onion rows. The difference in barley height may have resulted from the difference between the standard drill used to plant perpendicular rows and the modified planter used to plant parallel rows. The modified planter did not have packer wheels behind the drill openers, and the barley emerged a day later than that planted with the drill. Final stand was similar for both planters. The percentage of groundcover was greater when barley was planted perpendicular to the onion rows because there were more rows of barley.

During the 4 years of the study, barley no

Table 3. The effect of orientation of barley living mulch on number of onion bulbs harvested and onion yields.

\begin{tabular}{|c|c|c|c|c|c|c|c|c|}
\hline \multirow{2}{*}{$\begin{array}{l}\text { Barley } \\
\text { orientation }^{z}\end{array}$} & \multicolumn{4}{|c|}{ No. of bulbs harvested (1000s/ha) } & \multicolumn{4}{|c|}{ Onion yield $\left(\mathrm{Mg} \cdot \mathrm{ha}^{-1}\right)$} \\
\hline & Large $^{\mathrm{z}}$ & Medium $^{2}$ & Small $^{2}$ & Total & Large $^{z}$ & Medium $^{2}$ & Small $^{\mathrm{z}}$ & Total \\
\hline & \multicolumn{8}{|c|}{1995} \\
\hline Perpendicular & 79 & 116 & 48 & 272 & 22.8 & 18.5 & 3.2 & 49.5 \\
\hline Parallel & 69 & 104 & 46 & 247 & 20.4 & 16.7 & 3.1 & 44.7 \\
\hline \multirow[t]{2}{*}{ Probability } & NS & $*$ & NS & $*$ & NS & $*$ & NS & $*$ \\
\hline & \multicolumn{8}{|c|}{1996} \\
\hline Perpendicular & 134 & 175 & 72 & 430 & 38.0 & 28.0 & 4.6 & 77.5 \\
\hline Parallel & 162 & 193 & 72 & 458 & 46.0 & 31.0 & 4.8 & 87.3 \\
\hline \multirow[t]{2}{*}{ Probability } & NS & NS & NS & $* *$ & NS & NS & NS & $* *$ \\
\hline & \multicolumn{8}{|c|}{1997} \\
\hline Perpendicular & 131 & 141 & 67 & 378 & 37.8 & 21.6 & 4.2 & 69.0 \\
\hline Parallel & 125 & 132 & 88 & 385 & 37.3 & 19.9 & 5.4 & 68.5 \\
\hline \multirow[t]{2}{*}{ Probability } & NS & NS & NS & NS & NS & NS & NS & NS \\
\hline & \multicolumn{8}{|c|}{1998} \\
\hline Perpendicular & 142 & 139 & 57 & 351 & 41.8 & 21.6 & 3.6 & 69.2 \\
\hline Parallel & 178 & 124 & 39 & 354 & 53.7 & 20.1 & 2.4 & 79.0 \\
\hline Probability $^{\mathrm{x}}$ & $* *$ & NS & $*$ & NS & $*$ & NS & $*$ & $* *$ \\
\hline
\end{tabular}

${ }^{\mathrm{z}}$ Orientation of barley vs. onion rows.

y Large, medium, and small onions are $>7.6 \mathrm{~cm}, 5.7$ to $7.6 \mathrm{~cm}$, and $<5.6 \mathrm{~cm}$ in diameter, respectively. ns, ${ }^{*}, * *$ Nonsignificant or significant at $P \leq 0.05$ or 0.01 , respectively.

Table 4. Response of onions and barley (as measured on 2 July 1998) to the planting orientation and height of the barley living mulch when killed.

\begin{tabular}{|c|c|c|c|c|}
\hline $\begin{array}{l}\text { Barley living } \\
\text { mulch }\end{array}$ & $\begin{array}{c}\text { Barley } \\
\text { height } \\
(\mathrm{cm})\end{array}$ & $\begin{array}{l}\text { Onion } \\
\text { height } \\
(\mathrm{cm})\end{array}$ & $\begin{array}{c}\text { Onion } \\
\text { growth stage } \\
\text { (no. of leaves) }\end{array}$ & $\begin{array}{l}\text { Ground } \\
\text { cover }^{z} \\
(\%)\end{array}$ \\
\hline \multicolumn{5}{|c|}{ Height when killed $(\mathrm{cm})$} \\
\hline 10 & 0.0 & 35.9 & 6.5 & 2 \\
\hline 18 & 1.1 & 31.1 & 6.0 & 18 \\
\hline 23 & 6.7 & 29.2 & 5.5 & 34 \\
\hline 30 & 14.6 & 27.9 & 5.2 & 39 \\
\hline $\mathrm{LSD}_{0.05}$ & 2.3 & 1.9 & 0.4 & 12 \\
\hline Probability & $* * *$ & $* * *$ & $* * *$ & $* * *$ \\
\hline \multicolumn{5}{|c|}{$\underline{\text { Planting orientation }}^{\underline{ }}$} \\
\hline Perpendicular & 6.6 & 30.5 & 5.6 & 28 \\
\hline Parallel & 4.6 & 31.6 & 6.0 & 18 \\
\hline Probability & $*$ & NS & NS & $* *$ \\
\hline
\end{tabular}

${ }^{2}$ Percentage of ground covered with barley residue on 2 July. Determined using the line intercept method with a $0.9-\mathrm{m}$ ruler and taking counts every $2.5 \mathrm{~cm}$.

${ }^{y}$ Orientation of barley vs. onion rows.

Ns, ${ }^{*},{ }^{* *},{ }^{* * *}$ Nonsignificant or significant at $P \leq 0.05,0.01$, or 0.001 , respectively.

longer provided any groundcover around 1 June, 1 July, and mid-August when sprayed at 10,18 , and $23 \mathrm{~cm}$ tall, respectively. Barley sprayed when $30 \mathrm{~cm}$ tall provided groundcover for the entire season. By mid- to late June, onions are usually large enough (15 to $25 \mathrm{~cm}$ tall) to withstand the wind without windbreaks. Spraying the barley when it was $18 \mathrm{~cm}$ tall provided protection until that time.

\section{Literature Cited}

Barnes, J.P. and A.R. Putnam. 1983. Rye residues contribute weed suppression in no-tillage cropping systems. J. Chem. Ecol. 9:1045-1057.

Bottenberg, H., J. Masiunas, and C. Eastman. 1999. Strip tillage reduces yield loss of snapbean planted in rye mulch. HortTechnology 9:235-240.

Hewson, R.T. and H.A. Roberts. 1971. The effect of weed removal at different times on yield of bulb onions. J. Hort. Sci. 46:471-483.

Lanterman, W.S., D.T. Warholic, L.A. Ellerbrock, and P.J. Stachowski. 1984. Effects of fluazifop and barley windbreak competition on seeded onions in organic soil. Proc. Northeast Weed Sci. Soc. 39:184-187.

Masiunas, J.B., D.M. Eastburn, V.N. Mwaja, and C.E. Eastman. 1997. The impact of living and cover crop mulch systems on pests and yields of snap beans and cabbage. J. Sustainable Agr. 9(2/ 3):61-89.

Masiunas, J.B., L.A. Weston, and S.C. Weller. 1995. The impact of rye cover crops on weed populations in a tomato cropping system. Weed Sci. 43:318-323.

Mwaja, V.N., J.B. Masiunas, and C.E. Eastman. 1996. Rye (Secale cereale L.) and hairy vetch (Vicia villosa Roth) intercrop management in fresh-market vegetables. J. Amer. Soc. Hort. Sci. 121:586-591.

Nelson, W.A., B.A. Kahn, and B.W. Roberts. 1991. Screening cover crops for use in conservation tillage systems for vegetables following spring plowing. HortScience 26:860-862.

SAS Institute Inc. 1989. SAS/STAT user's guide, ver. 6, 4th ed., vol. 2, Cary, N.C

Schonbeck, M., S. Herbert, R. DeGregorio, F. Mangan, K. Guillard, E. Sideman, J. Herbst, and R. Jaye. 1993. Cover cropping systems for brassicas in the northeastern United States: 1. Cover crop and vegetable yields, nutrients and soil conditions. J. Sustainable Agr. 3(3/4):105-132.

Wicks, G.A., D.N. Johnston, D.S. Nuland, and E.J. Kinbacher. 1973. Competition between annual weeds and sweet Spanish onions. Weed Sci. 21:436-439.

Zandstra, B.H. and D.D. Warncke. 1993. Interplanted barley and rye in carrots and onions. HortTechnology 3:214-218. 